\title{
"B” (Accompanying My Daughter Through Life): Critical Discourse Analysis
}

\author{
Marcela González Hage \\ University of Guanajuato, MEXICO \\ Division of Social Sciences and Humanities
}

Received: 9 June 2021 - Accepted: 30 July 2021 - Published Online: 24 October 2021

\section{Abstract}

This study analyzes the poem "B" by Sarah Kay, through the interpretation of the various metaphors that compose it. This was poem was first published in 2011 and it is a love letter that the author sends the daughter she does not yet have. In order to do this a critical discourse analysis methodology is used (Fairclough, 1995), as well as an interpretation of the metaphors that are present in the poem (Lakoff, 2003).

Keywords: Sarah Key, “B”, critical discourse analysis.

\section{Introduction}

Throughout history women have played different roles in society and in many cases they have had to endure difficult situations that have brought them to fight for their rights, and much has been achieved. The poem that is analyzed in this paper is called B, by Sarah Kay who is an American poet educator who travels across the United States and all around the world teaching poetry, and performs spoken word poetry. She has written four books of poetry and she became well known because of her performance of this poem in a TED Talk in 2011 (Project Voice, n.d.).

The poem shows a reflection from a woman who lets the audience see what life looks like through her eyes. She embraces the idea of maybe becoming a mother to a girl, and showing her that even when life has wonderful moments, it will not always be easy to enjoy the ride. Analyzing this text is relevant because it expresses what some of the feelings that a woman in a context like Kay's experiences in life, some of her joys, but also some of her fears. What is trying to be analyzed in this paper is what metaphors the author uses to describe life as a woman and what message they convey.

In order to do this, I will use critical discourse analysis (CDA) which is a methodology that looks not only into the text itself, but also the context where it was born and how it was created (Fairclough, 19995). I will also analyze the metaphors that the author used to describe her feelings about life as a woman, based on Lakoff's (2003) work.

(C) Authors. Terms and conditions of Creative Commons Attribution 4.0 International (CC BY 4.0) apply. Correspondence: Marcela González Hage, Universidad de Guanajuato, División de Ciencias Sociales y Humanidades, Guanajuato, MEXICO. E-mail: marcelaghage@gmail.com. 


\section{Literature review}

This section provides an overview of CDA and the use of metaphors, which serve as the framework used to analyze the poem. It also invites the reader on a short trip through the history of the feminist movement, since this seems to inspire the essence of the poem that is being analyzed.

\subsection{Critical discourse analysis}

According to Fairclough (1995), discourse understood from a linguistic point of view goes beyond a text, which can be written or spoken, it includes other forms of communication such as non-verbal and symbols that make language to be a "form of social practice" (p. 7). This means that language and the use that it is given help shape the way that people interact with each other, and also it is a means to spread and reproduce ideologies and ways of acting.

He describes critical discourse analysis as a framework that integrates "(a) analysis of text, (b) analysis of processes of text production, consumption and distribution, and (c) sociocultural analysis of the discursive event [...] as a whole" (Fairclough, 1995: 25). It offers a critical point of view about the discourse that is being analyzed, allowing us to understand the ideologies that underlie it.

\subsection{Metaphors}

Metaphors are a valuable resource found in texts that is largely used poetry, because of the richness that offers to it. This paper analyzes the poem from a CDA point of view, but also looks at the metaphors because, as stated by Charteris-Black (2004: 28) cited in Hart (2007: 2): "metaphor is ... central to critical discourse analysis since it is concerned with forming a coherent view of reality". It can be interpreted that metaphors allow the audience to comprehend what is often a subjective experience, such as political points of view, emotions, and spiritual experiences, among others.

For the purpose of this analysis, I used Lakoff's (2003) classification of the types of metaphors that can be found. He affirms that "human thought processes are largely metaphorical" (p. 7), this means that humans are constantly using metaphors to interpret and interact with the world that surrounds them. Therefore, it is quite natural for people to communicate using them, this makes expressing their feelings, thoughts and emotions easier, as these resources make concrete what is abstract. In addition, metaphors let the speaker juggle with the words so it highlights what is important to communicate and hides what is not.

The metaphors found in this poem can be classified under four different types. I will now mention them and briefly describe them:

- Conduit metaphors: The idea, which is usually put into objects, and the words which are the containers of the idea. It is sent to the recipient of the message along a conduit. The recipient receives it and interprets it to get the message that was conveyed. They are easily understood without the need of providing additional context.

- Ontological metaphors: These take parts of our experiences and allow us to categorize them. They serve different purposes, such as refer to various concepts, quantify, identify aspects, identify causes, as well as set goals and motivate actions.

- Personification metaphors: This type of metaphors take non-human objects and give them human characteristics, such as capabilities that are exclusive of people. 
- Metonyms: It takes an entity in order to talk about a whole, meaning that only a part of it is mentioned in the metaphor, but the entire subject is referred to.

Although Lakoff offers a more extense taxonomy, for the purpose of this paper I only include the types that were taken into account to interpret the metaphors that appear in this poem.

\subsection{Introduction to feminism}

In this section I give a brief overview of what feminism is, addressing some of the most important moments in the history of the feminist movement. I also mention some of the milestones that have been achieved throughout its history. Finally, I invite the reader to pay special attention to the third feminism wave, as it is the one I am using as a reference to analyze this poem.

The feminist movement has been present in human's history for centuries and although its demands have varied throughout time, its main goal has not changed. It can be summarized in Faludi's (1991) words: "Feminism asks the world to recognize at long last that women aren't decorative ornaments, worthy vessels, members of a 'special-interest' group" (p. 15). This can be interpreted in various forms, whether it is demanding safety, equal job opportunities and salaries to men, or having the choice to make their own decisions, women seek recognition of their worth through the feminist movement.

I now present a summary of the transit of feminism through history based on the wonderful work done by Jenainati and Groves (2007).

Originally women were mostly considered to be someone's possession, either their daughter or wife, and when married even their bodies belonged to their husbands. In addition, they did not have formal rights, and it was almost impossible for them to receive higher education, if any education at all. Women were suppressed by patriarchy, which in Weedon's (1987) words is defined as "power relations in which women's interests are subordinated to the interests of men" (p. 2). This means that they were expected to be at home, serving their husband's needs, and raising their kids, no matter what their own interests or desires were.

\subsubsection{First feminism wave}

The first wave feminism goes back some centuries and it is possible to identify some political actions, in certain contexts, that must have served as inspiration to more women to keep nurturing the movement.

In 1642 London was the scenario where a group of women who worked in different types of businesses, united and marched to the Houses of Lords and Commons to ask for the law to consider the conditions of the working class and improve them. This was the beginning of many other protests that women led whenever they or their class were discriminated against by political decisions. Although this did not receive the name of feminism or feminist movement, it is clearly one of the earliest moments in history when women gathered seeking a common goal.

The $18^{\text {th }}$ and $19^{\text {th }}$ centuries were illuminated with the presence of female figures who addressed the subordination to men that women experienced through their writing. This movement followed the Age of Enlightenment and inspired by it, the use of the reason instead of only trusting faith.

This first wave feminism achieved the recognition of some women's rights and also the first steps were taken of a long journey to grant women the right to vote. One of the milestones of this first wave of feminism was that by mid 1900 s women were free to vote in most countries. 


\subsubsection{Second feminism wave}

The second feminism wave can be located from the 1960 s on to the 1980 s approximately. The term was first coined by Marsha Lear in 1968 in an article written for The New York Times, and it made reference to the feminist activity in different countries. This wave emphasized that women's oppression is rooted in social constructs, and this led to the creation of two political movements: Women's Rights Movement (WRM) and Women's Liberation Movement (WLM). Even when both movements sought to achieve the recognition of women's rights, the WRM was mostly constituted by women who were part of the working class. They demanded better working rights and conditions for women. The WLM had clear demands that the supporters of the movement wanted to achieve (Jenainati \& Groves, 2007: 163):

1. Equal pay for men and women;

2. Equal education and job opportunities;

3. Free 24-hour nurseries;

4. Free contraception and abortion on demand;

5. Financial and legal independence;

6. An end to discrimination against lesbians and a woman's right to define her sexuality;

7. Freedom from intimidation by threat or use of violence and an end to male aggression and dominance.

This wave was influenced by some important female figures such as Virginia Woolf, Betty Friedan, and Simone de Beauvoir, who through their writing offered a glance to the injustices and discrimination that women still suffered. They wanted to raise awareness of this situation and offer theoretical support to the feminist movement, based on existing philosophies, such as existentialism. This philosophical movement claims that a person exists and then becomes something based on their actions. De Beauvoir took this principle as theoretical base to state that women, just like men, should be able to control their actions without having anyone limiting their decisions. Betty Friedan participated in this movement by exposing the struggle that women in the late 1900 s had trying to balance their working lives and their roles as mothers and at home. She suggested that the feminist movement had to be rebuilt from scratch, and men needed to be involved in it. I consider that this is a very modern point of view of the feminist movement, as today it is thought not to be only a women's movement, but a humanity's movement.

Some of the milestones conquered in the second feminist wave are related to women's participation on the decision making of how big their family would be, this had as a result the development of the first oral contraceptive for women. Also, the violence against women, which had commonly been normalized, started to be more and more penalized, whether this took place at home or elsewhere. Furthermore, commissions and institutions have been created in many countries to provide assistance to women whose rights are being violated or who are being discriminated against. In addition, thanks to the feminist movement same-sex couples have gained the right to marry and even adopt children in some countries.

The feminist movement has grown stronger throughout time; however, it has had to face some setbacks during the process. In the 1980 s it was under attack by different actors of social life, such as academics, journalists, to name a few. They claimed that women had already reached their goal of having their rights recognized, and that they should go back to performing their roles at home, enjoying what had been gained. Fortunately, these women have never stopped fighting for what they deserve and they have conquered a very important place in today's political, economic and social world. 


\subsubsection{Third wave feminism}

All waves of feminism have been influenced by the context of their historical time and have faced their own problems and challenges. However, the third wave feminism has turned to be difficult in a different way than the previous waves faced. According to Shelley Budgeon's collaboration in Gill and Scharff's book (2011), the third wave feminism rejects the binary accepted codes used in the previous generations, which has caused contradictions. During the last decades genders' social roles have turned liquid and they are constantly changing and restructuring. This has caused that femininity, feminism, gender and their meanings are questioned, as they are no longer what they meant in the previous waves and they need to be rethought.

Bugdgeon (2001) emphasizes the characteristics of today's society regarding gender, which get more visible every passing day. She mentions since today we find large groups of transgender, bisexual, and interracial people, it is hard to talk about only women when it comes to feminism. Feminism nowadays has to focus on individual needs rather than on a gender's needs, which can be ambiguous and complicated to identify. "By advocating an analytical move away from understanding gender in collective terms third-wave feminism often promotes a 'politics of difference' starting from the specificity of individual experience" (p. 282). This implies that the feminist movement in its third wave has to be inclusive and the feminist activities can take different paths.

Based on this, the third wave feminism intends to create a feminism that will be reshaped over and over again, making room for everyone to fit in it, but following very specific characteristics that are representative of it. Some examples are the culture of do it yourself (DIY), which promotes the independence of each individual and their empowerment. Also, in the third wave feminism, the empowerment of the oppressed genders is desired and sought.

Although much has been done, and life is in certain aspects notoriously easier than it used to be for women, there is still much more to achieve. Women around the world are still suffering violence in different forms, and oftentimes their rights keep on being neglected or in cases, not even acknowledged. Not until every woman has the possibility to make their own decisions and feel free and safe while doing it, we could say that the feminist movement has reached its main goal. I will venture now and say that this is part of what Sarah Kay wants to express in her poem "B", that life is always complicated, but especially if you are a woman. Nevertheless, it is a wonderful path to travel and must be enjoyed.

\section{Methodology}

As it has previously been mentioned this poem was first published in 2011, which means that it responds to a somewhat recent context, in terms of what women experience nowadays. I chose this poem because I consider that the message that is sent is worth being analyzed, as it offers and opportunity for almost anyone to feel identified with it, because situations that compose life are present there. However, although she never specifically mentions that she is narrating a woman's experience exclusively, she does let the audience know that she thinks of life being tougher on women by talking to a hypothetical daughter - and not a son. She does this through the use of metaphors.

I will now proceed to describe the methodology that was followed to come up with the findings that are presented in the following section. As it has previously been mentioned, the poem was analyzed under the CDA methodology in combination with a metaphor analysis.

As a reminder to the reader, what I sought to analyze in this poem was what metaphors the author uses to describe life as a woman and what message they convey. I selected this text 
because I considered that this poem expresses very clearly what the joys and struggles that women experience are, set in the context of a middle class a western society in the twenty-first century.

After selecting the theoretical framework that I considered more appropriate for developing this analysis, I briefly described it so the reader knows what I based on to carry out the analysis. Next, I did a literature review on feminism and the feminist waves, in order to provide the reader with a summary of how the movement has developed throughout time. This helped me highlight what have been the main goals and conflicts that are the most representative of each wave, and the third wave feminism contextualizes the poem in its own time.

Finally, after identifying the categories suggested by Lakoff to classify metaphors, I was able to offer a classification and interpretation of the various metaphors that compose the poem. In order to do this, I went over the metaphors that are in the poem and identified the different types that the author uses. Then I was able to offer an interpretation to them. I present all this in a table to facilitate the comprehension. Sometimes more than one metaphor will be found in the same line of the table, this is not to cut ideas and allow the analysis to flow.

\section{Findings and discussion}

In this section I take the metaphors in the poem and offer an interpretation to each one of them, as well as I classify them based on four Lakoff's categories. I also present an interpretation to them to unveil what the author means when she writes them. I ought to mention that this is a personal interpretation and can be revisited for further revision in the future.

\begin{tabular}{|c|c|c|}
\hline Metaphor & Interpretation & Classification \\
\hline $\begin{array}{l}\text { She's going to call me Point B, because } \\
\text { that way she knows that no matter what } \\
\text { happens, at least she can always find } \\
\text { her way to me. }\end{array}$ & $\begin{array}{l}\text { What the author means is that even when } \\
\text { her daughter, if she had one, was to be free } \\
\text { to experience life on her own, she would } \\
\text { always be there to support and comfort her. } \\
\text { Life, she predicts, is not going to be easy. }\end{array}$ & $\begin{array}{l}\text { This is a conduit metaphor. It takes an } \\
\text { idea, puts it into words and expresses it } \\
\text { in a way that the audience can } \\
\text { understand it without any trouble. }\end{array}$ \\
\hline $\begin{array}{l}\text { And I am going to paint the Solar } \\
\text { Systems on the backs of her hands, so } \\
\text { she has to learn the entire universe } \\
\text { before she can say 'Oh, I know that like } \\
\text { the back of my hand'. }\end{array}$ & $\begin{array}{l}\text { With this metaphor she lets the audience } \\
\text { know that she seeks to teach her daughter } \\
\text { to be humble. She wants to make sure that } \\
\text { her daughter is able to listen to the facts and } \\
\text { what others have to say, so she can } \\
\text { formulate an opinion of her own. She } \\
\text { intends to raise a daughter who will be able } \\
\text { to recognize her mistakes and her } \\
\text { limitations. }\end{array}$ & $\begin{array}{l}\text { In this section of the poem a conduit } \\
\text { metaphor and an ontological metaphor } \\
\text { motivating actions can be found. "I am } \\
\text { going to paint the Solar Systems in the } \\
\text { backs of her hands" falls under the first } \\
\text { category. It is expected that the } \\
\text { audience understands that the author } \\
\text { does not plan to paint the hands of her } \\
\text { daughter, it is a poetic resource to } \\
\text { express what has already been } \\
\text { interpreted. "...so she has to learn the } \\
\text { entire universe before she can say 'Oh, } \\
\text { I know that like the back of my hand" } \\
\text { corresponds to the latter category. It } \\
\text { tries to prevent the author's daughter } \\
\text { from making a fool of herself acting } \\
\text { recklessly. }\end{array}$ \\
\hline $\begin{array}{l}\text { This life will hit you, hard, } \\
\text { in the face, wait for you to get back up, } \\
\text { just so it can kick you in the stomach } \\
\text { but getting the wind knocked out of you } \\
\text { is the only way to remind your lungs } \\
\text { how much they like the taste of air. }\end{array}$ & $\begin{array}{l}\text { The author is aware of the difficulties and } \\
\text { hard times that her daughter will most } \\
\text { likely have to go through, as life is not } \\
\text { always easy. However, she is able to } \\
\text { transmit a positive message acknowledging } \\
\text { that enduring hard times has the possibility } \\
\text { of making us value and enjoy the good } \\
\text { times when they come. I consider that this } \\
\text { metaphor is powerful because it presents } \\
\text { the audience the possibility to take } \\
\text { advantage of the good and the bad that life } \\
\text { offers us. }\end{array}$ & $\begin{array}{l}\text { This section is composed by } \\
\text { personification metaphors. } \\
\text { Expressions such as "will hit you, } \\
\text { hard", "kick you in the stomach" are } \\
\text { used as utterances that personify life, } \\
\text { they assign it human characteristics, } \\
\text { such as the possibility of hurting } \\
\text { someone physically and causing them } \\
\text { pain. The same thing happens with the } \\
\text { expression, "...the only way to remind } \\
\text { your lungs how much they like the taste } \\
\text { of air". In this case lungs are thought as } \\
\text { being able to remember and like things: } \\
\text { human characteristics. And when } \\
\text { analyzed in detail one concludes that } \\
\text { the author is not referring to actual }\end{array}$ \\
\hline
\end{tabular}




\begin{tabular}{|c|c|c|}
\hline & & $\begin{array}{l}\text { lungs, but to the sense of peace that } \\
\text { comes after experiencing pain and } \\
\text { despair. }\end{array}$ \\
\hline $\begin{array}{l}\text { There is hurt, that cannot be fixed by } \\
\text { band aids or poetry, so the first time } \\
\text { she realizes that Wonder Woman isn't } \\
\text { coming I'll make sure she knows she } \\
\text { does not have to wear the cape all by } \\
\text { herself. Because no matter how wide } \\
\text { you stretch your fingers, your hands } \\
\text { will always be too small to catch all the } \\
\text { pain you want to heal. Believe me, I've } \\
\text { tried. }\end{array}$ & $\begin{array}{l}\text { The author is aware that life can be hurtful } \\
\text { sometimes, and that the pain that certain } \\
\text { circumstances can cause might be difficult } \\
\text { to overcome. It also occasionally stays } \\
\text { around longer than expected. She is also } \\
\text { sensitive to young people's eagerness to } \\
\text { help others and make a change in the world. } \\
\text { Therefore, she tries to tell her daughter that } \\
\text { there will be times in life when she will feel } \\
\text { the responsibility to stand up for others, or } \\
\text { at least to help those around her and this is } \\
\text { fine. Nevertheless, she also wants her } \\
\text { daughter to know that is not alone in life } \\
\text { and she should always feel free to ask for } \\
\text { help. There is much to be done in this } \\
\text { world, it is impossible for a single person to } \\
\text { help everyone. }\end{array}$ & $\begin{array}{l}\text { In this section we find ontological } \\
\text { metaphors, specifically the one } \\
\text { referring to "hurt". This points out that } \\
\text { there are hard situations in life and is } \\
\text { followed by a conduit metaphor. } \\
\text { Wonder Woman conveys the message } \\
\text { that the author's daughter does not } \\
\text { need focuses the attention on quantity, } \\
\text { when it mentions "all the pain you want } \\
\text { to heal". Although it is not possible to } \\
\text { count how much pain that is, it to be } \\
\text { alone in life. Finally, there is also an } \\
\text { ontological metaphor that lets the } \\
\text { audience know that is not little. }\end{array}$ \\
\hline $\begin{array}{l}\text { Don't keep your nose up in the air like } \\
\text { that I know that trick, I've done it a } \\
\text { million times. You're just smelling for } \\
\text { smoke so you can follow the trail } \\
\text { back to a burning house so you can find } \\
\text { the boy who lost everything in the fire } \\
\text { to see if you can save him. Or else find } \\
\text { the boy who lit the fire in the first place } \\
\text { to see if you can change him. } \\
\text { But I know she will anyway, so instead, } \\
\text { I'll always keep an extra supply of } \\
\text { chocolate and rain boots nearby. } \\
\text { Because there is no heartbreak that } \\
\text { chocolate can't fix. Ok, there's a few } \\
\text { heartbreaks that chocolate can't fix, but } \\
\text { that's what the rain boots are for, } \\
\text { because rain will wash away everything } \\
\text { if you let it. }\end{array}$ & $\begin{array}{l}\text { The author knows that young people are } \\
\text { often attracted to situations that might end } \\
\text { up hurting or endangering them. This could } \\
\text { be translated into making bad decisions, } \\
\text { making mistakes or choosing poorly their } \\
\text { friends and partners. She is aware of this, } \\
\text { probably because she has experienced it in } \\
\text { the past. } \\
\text { She is trying to prevent her daughter from } \\
\text { experiencing heartache, because like any } \\
\text { mother she does not want to see her } \\
\text { suffering. Although she is aware that } \\
\text { heartaches are part of life and that everyone } \\
\text { needs to go through them in order to learn } \\
\text { to make better choices in the future. She } \\
\text { offers here a couple of remedies to pain: } \\
\text { chocolate and rain. Chocolate, among } \\
\text { others, is commonly a symbol of comfort } \\
\text { for people who are going through difficult } \\
\text { moments. This is a way that the author } \\
\text { finds to tell her daughter that she will } \\
\text { always be able to find comfort by her side. } \\
\text { The second metaphor that she uses is rain } \\
\text { water, as this washes and flows, never stays. } \\
\text { She intends to let her daughter know that } \\
\text { no matter how much she is suffering, pain } \\
\text { will not last forever, but she needs to let it } \\
\text { pass and take the lessons that it was there } \\
\text { to teach her. }\end{array}$ & $\begin{array}{l}\text { The utterance "don't keep your nose up } \\
\text { in the air" is a metonym that focuses on } \\
\text { just a part of the element to refer to the } \\
\text { whole. The author is not really taking } \\
\text { about her nose, but is hoping that she } \\
\text { will stay out of trouble. } \\
\text { "You are just smelling for smoke [...] to } \\
\text { see if you can save him" is a conduit } \\
\text { metaphor that takes the idea of trouble } \\
\text { and uses the smoke of a burning house } \\
\text { as resource to express it poetically. The } \\
\text { same thing occurs when she refers to } \\
\text { "the boy who lost everything in the fire/ } \\
\text { lit the fire". These conduit metaphors } \\
\text { talk about the boy's past and what he is } \\
\text { like nowadays. } \\
\text { Chocolate and rain are personification } \\
\text { metaphors, as they both are presented } \\
\text { as healing elements, they are thought to } \\
\text { be able to "fix and wash" what is } \\
\text { wronging the person who is in pain. } \\
\text { These actions are found in people. }\end{array}$ \\
\hline $\begin{array}{l}\text { When you open your hands to catch, } \\
\text { and wind up with only blisters and } \\
\text { bruises. When you step out of the } \\
\text { phone booth and try to fly, and the very } \\
\text { people you want to save are the ones } \\
\text { standing on your cape. } \\
\text { When your boots will fill with rain and } \\
\text { you'll be up to your knees in } \\
\text { disappointment }\end{array}$ & $\begin{array}{l}\text { There will also be times in life, the author } \\
\text { foresees, when her daughter will try to do } \\
\text { good and will end up hurt and } \\
\text { disappointed, due to her innocence in a } \\
\text { world that is immersed in an oppressive } \\
\text { system. }\end{array}$ & $\begin{array}{l}\text { All metaphors that are found in this } \\
\text { section fall under the category of } \\
\text { conduit metaphors. They take the idea } \\
\text { of trying to help others and end up } \\
\text { being frustrated and disappointed, and } \\
\text { express it using a variety of objects. }\end{array}$ \\
\hline $\begin{array}{l}\text { There's nothing more beautiful than } \\
\text { the way the ocean refuses to stop } \\
\text { kissing the shoreline no matter how } \\
\text { many times it is sent away. }\end{array}$ & $\begin{array}{l}\text { This metaphor is a powerful way that the } \\
\text { author finds to tell her daughter that she } \\
\text { will probably find a large number of } \\
\text { problems in her way to achieving her goals. } \\
\text { She might have to face rejection, injustices, } \\
\text { discrimination, and many other situations, } \\
\text { but she must never give up. Only } \\
\text { persistence and passion can make her get } \\
\text { what she works for. }\end{array}$ & $\begin{array}{l}\text { Another personification metaphor can } \\
\text { be found here. The idea of not giving up } \\
\text { on one's dreams, no matter what the } \\
\text { obstacles are, is conveyed using the } \\
\text { ocean and shoreline. They are } \\
\text { attributed the capability of refusing to } \\
\text { stop kissing and sending something/ } \\
\text { someone away. }\end{array}$ \\
\hline $\begin{array}{l}\text { This world is made out of sugar. } \\
\text { It can crumble so easily. But don't be }\end{array}$ & $\begin{array}{l}\text { I find this metaphor to be a beautiful way of } \\
\text { showing how fragile life can be, one day we } \\
\text { are here and the next day we may no longer }\end{array}$ & $\begin{array}{l}\text { "...is made out of } \text { sugar. } \\
\text { It can crumble so easily" is an } \\
\text { ontological metaphor that refers to the }\end{array}$ \\
\hline
\end{tabular}




\begin{tabular}{|c|c|c|}
\hline $\begin{array}{l}\text { afraid to stick your tongue out and taste } \\
\text { it. }\end{array}$ & $\begin{array}{l}\text { be. Things can change so abruptly; this is } \\
\text { why it is important to enjoy what life has to } \\
\text { offer. }\end{array}$ & $\begin{array}{l}\text { fragility of life. However, the "stick your } \\
\text { tongue and taste it" is a conduit } \\
\text { metaphor that offers advice to the } \\
\text { author's daughter on how to enjoy it. }\end{array}$ \\
\hline $\begin{array}{l}\text { Remember your mama is a worrier and } \\
\text { your papa is a warrior. And you're the } \\
\text { girl with small hands and big eyes who } \\
\text { never stops asking for more. } \\
\text { Don't you ever apologize for the way } \\
\text { your eyes refuse to stop shining, your } \\
\text { voice is small but don't ever stop } \\
\text { singing. }\end{array}$ & $\begin{array}{l}\text { I consider this metaphor to be a clear image } \\
\text { of what family means to the author, and the } \\
\text { roles that each person plays within the } \\
\text { family organization. The mother, being } \\
\text { represented as a worrier, gives the audience } \\
\text { the idea that a mother will always care } \\
\text { about her children. They will always } \\
\text { represent something she needs to worry } \\
\text { about in a world full of danger. The father, } \\
\text { shown as a warrior, represents someone } \\
\text { who will always protect his family and who } \\
\text { will be ready to fight whoever dares to } \\
\text { threaten them in any way. The girl who } \\
\text { never stops asking for more is someone } \\
\text { who will never give up until she achieves } \\
\text { her goals, and who will question the } \\
\text { injustices she sees. }\end{array}$ & $\begin{array}{l}\text { "Worrier", "warrior", and "girl with } \\
\text { small hands and big eyes who never } \\
\text { stops asking for more" are ontological } \\
\text { metaphors that help the audience } \\
\text { identify aspects that are meant to be } \\
\text { highlighted by the author. They refer to } \\
\text { the personality of each character } \\
\text { involved. } \\
\text { "Your eyes refuse to stop shining" is a } \\
\text { personalization metaphor that, once } \\
\text { again, focuses on the personality of the } \\
\text { author's daughter. }\end{array}$ \\
\hline $\begin{array}{l}\text { And when they finally hand you a } \\
\text { heartache, when they slip war and } \\
\text { hatred under your door and offer you } \\
\text { handouts on street corners of cynicism } \\
\text { and defeat you tell them that they really } \\
\text { ought to meet your mother. }\end{array}$ & $\begin{array}{l}\text { With this final metaphor the author tries to } \\
\text { tell her daughter that she will have to see } \\
\text { war and hatred, they are part of life, but she } \\
\text { must not get enrolled in them. She also } \\
\text { knows that this can sometimes make her } \\
\text { feel like she cannot take it any longer and } \\
\text { that she is ready to give up. When this } \\
\text { happens, she wants her daughter to } \\
\text { remember everything she taught her and } \\
\text { also that she is there to support her in her } \\
\text { journey. }\end{array}$ & $\begin{array}{l}\text { This last section of the poem can also be } \\
\text { interpreted through conduit } \\
\text { metaphors, which take the idea of those } \\
\text { negative thoughts and emotions that } \\
\text { are present in life, and use "hand you a } \\
\text { heartache". "Slip war and hatred", } \\
\text { "handouts of cynicism and defeat" as } \\
\text { means express them. }\end{array}$ \\
\hline
\end{tabular}

\section{Conclusions}

This poem was analyzed based on the CDA framework that considers that the discourse goes far beyond what is written, this means that the message and the way it was conveyed requires additional interpretation. In this case, the analysis of the metaphors under Lakoff's classification allowed us to see not only what the main categories that Kay uses in her poem are, but also the message she sends to her audience.

After analyzing this poem, I conclude that this author is someone who has gone through hard times in life, when she has been hurt and belittled, but who has also had the opportunity to enjoy life's greatness, and she considers worthwhile spreading a positive message. In addition, even when she does not speak only to women, she does let the audience know what she considers life to be like for us. I thing this poem is a perfect balance between showing the way previous generations have been educated, where women's voices were less heard and were expected to be weaker, and the empowerment that women have achieved in the last decades.

\section{Acknowledgements}

This research did not receive any specific grant from funding agencies in the public commercial, or not-for-profit sectors.

The authors declare no competing interests. 


\section{References}

Budgeon, S. (2001). Third wave feminism and the politics of gender in late modernity. Palgrave Macmillan.

Fairclough, N. (1995). Critical discourse analysis: the critical study of language. Longman.

Faludi, S. (1991). Backlash. The undeclared war against American women. Three rivers press.

Gill, R., \& Scarff, C. (2011). New feminities. Palgrave Macmillan.

Hart, C. (2007). Critical discourse analysis and metaphor: Toward a theoretical framework. University of Hertfordshire.

Jenainati, C., \& Groves, J. (2007). Introducing feminism. Icon Books Ltd.

Kay, S. (2014). No matter the wreckage. Write bloody publishing.

Lakoff, G. (2003). Metaphors we live by. London: The university of Chicago press.

Project Voice (2021, May 15). Our team. Project Voice. https://www.projectvoice.co/team.

Weedon, C. (1987). Feminist practice and poststructuralist theory. Blackwell. 
M. González Hage - “B” (Accompanying My Daughter Through Life): Critical Discourse Analysis

C O A $\mathbf{s}$ 